article, using the comparative method. The reasons for the well-established, widespread (up to $95 \%$ of the total number of criminal cases) practice of the American law enforcement in terms of concluding plea agreements are revealed, advantages of such institution in the aspect of counteracting economic crimes are demonstrated. Historical preconditions and genesis of this legal institution, which was first developed by the English common law, but then began to be actively used in the United States in the middle of the twentieth century, are revealed. Against this background, the domestic analogue, relatively recently introduced into the legal system, in connection with the adoption of the current CCP, is currently perceived as a somewhat underdeveloped, relatively uncommon (up to $15-20 \%$ of the total number of initiated criminal cases) institution, while possessing significant potential for law enforcement development.

It is stated that, as with any legal agreement (contract), in practice there are many situations, when a plea agreement is violated by one of its parties. Given that this type of procedural agreement directly covers the constitutional rights of American citizens, violation of its terms may raise serious objections to compliance with the constitutional imperative of due process.

The author's position that the Art. 389-1 of the Criminal Code, establishing criminal liability for intentional non-compliance with the conciliation agreement or the recognition of innocence, is a manifestation of erroneous criminalization and thus should be excluded. The practice of imposing a real sentence on the basis of a conviction for breach of agreement can, on the one hand, ensure that the convict respects the terms of the agreement and, on the other, guarantee that the court imposes a more severe punishment in case of non-compliance.

Keywords: plea agreement, economic offense, criminal liability, punishment, law enforcement practice, procedural status.

DOI: $10.33766 / 2524-0323.92 .166-176$

УДК 343.98

A. Kovalenko,

Phd in Law, Associate Professor in the Chair of Criminal-Law Disciplines Luhansk State University of Internal Affairs named after E. Didorenko (Sievierodonetsk, Ukraine) e-mail: new4or@gmail.com

iDhttps://orcid.org/0000-0003-3665-0147

\title{
THE SOURCES OF FORENSIC RECOMMENDATIONS FOR COLLECTION, EXAMINATION AND USE OF EVIDENCE IN CRIMINAL PROCEEDINGS
}

The article is devoted to identifying the main sources of forensic recommendations for the collection, examination and use of evidence in criminal proceedings. The author emphasizes that the relevance, sufficiency, practicality and methodological literacy of these recommendations should be ensured by the use of appropriate scientifically sound sources for their formation.

The sources of formation of such recommendations are: the most relevant provisions of forensic science; provisions of the legislation of Ukraine on criminal liability and provisions of the science of criminal law; provisions of the criminal procedural legislation of Ukraine and achievements of science of criminal procedure; legal positions formulated by the European Court of Human Rights; the practice of detection, investigation and trial of criminal offenses;

(C) Kovalenko A., 2020 
scientific provisions of other (non-legal) sciences, which are integrated by forensic science and implemented in law enforcement practice.

Key words: criminal proceeding, evidence, collection, research, use of evidence, forensic recommendations.

Formulation of the problem. Bringing a person to criminal responsibility is a very important and very liable activity. Any mistake by the authorities can lead to the unjust punishment of innocent people, criminals avoiding responsibility and continuing to harm society. Therefore, criminal procedure is very carefully regulated, and the requirements and standards for criminal prosecution are clearly established by both national and international law.

Proving is an integral part of any criminal procedure. The availability of profession ally developed and practice-oriented forensic recommendations for the collection, examination and use of evidence in criminal proceedings is one of the necessary conditions for ensuring the effectiveness of pre-trial investigation, fair trial and access of individuals to fast and efficient justice in criminal proceedings. At the same time, the issue of sources of forming and maintaining the relevance of such recommendations remains unsolved.

Analysis of recent publications. In the forensic literature, issues related to the collection, examination and use of evidence have been reflected in the works of such scientists as V. Bakhin, R. Belkin, V. Bernaz, A. Vinberg, I. Vozgrin, L. Drapkin, A. Dulov, V. Zhuravel, O. Kolesnichenko, V. Kolmakov, V. Konovalova, V. Lysenko, M. Lisov, V. Lisichenko, M. Saltevsky, M. Segai, M. Selivanov, V. Shepitko, N. Yablokov and many others. However, the list of sources for formulating forensic recommendations for the collection, examination and use of evidence in criminal proceedings has not yet been identified and substantiated in the specialized literature.

Formulation of goals. The goal of the research is to identify the main sources of forensic recommendations for the collection, examination and use of evidence in criminal proceedings as a part of theoretical and praxeological foundations of the eponymous forensic doctrine.

Presenting main material. Forensics, as an applied legal science, at the present stage of its existence explores two types of human activity: the activity of people who commit criminal offenses and the activity of officials who detect, investigate and prevent criminal offenses [1, p. 429]. One of the main tasks of this science is to develop recommendations aimed at improving the efficiency of the latter type of activity.

Among the tasks of criminal proceedings, Criminal Procedure Code of Ukraine considers provision of quick, comprehensive and impartial investigation and trial in order that everyone who committed a criminal offence were prosecuted in proportion to their guilt, no one innocent were accused or convicted, and no one were subjected to ungrounded procedural compulsion and that an appropriate legal procedure applied to each party to criminal proceedings [2]. The above-mentioned provisions correspond to Article 6 of the European Convention on Human Rights. According to the content of the article, everyone is entitled to a fair and public hearing within a reasonable time by an independent and impartial tribunal established by law, that will determine any criminal charge against him [3]. We believe that based on natural law values, the cited provision is subject to disseminating interpretation. Thus, the right to a fair trial applies not only to 
the ones prosecuted, but also to victims of offenses who deserve prompt satisfaction, as well as to all other persons for whom an effective law enforcement system guarantees the protection of their rights and freedoms.

In the context of the case law of the European Court of Human Rights (hereinafter referred to as the ECtHR), the case law of national courts of Ukraine, prompt and effective pre-trial investigation is an essential guarantee of the effectiveness of criminal proceedings in general and a necessary condition for ensuring access to justice in criminal cases. The significance of the stage of pre-trial investigation is also manifested in the fact that it is at this stage of the criminal proceedings that the main part of the evidence base is formed, which the parties of the proceedings will operate before the court.

In its decision in Zorina and Others v. Ukraine [4], the ECtHR formulates some criteria for the effectiveness of a pre-trial investigation, including: the appropriateness of investigative actions, the promptness and reasonable speed of the investigation, the involvement of the victim's family and the independence of the investigation. Another such criterion is the thoroughness of the investigation, which is that public authorities should take all appropriate and available measures to ensure the collection of evidence on events, inter alia, witness statements and forensic examinations. Obviously, in order to ensure respect for the right of access to justice, a trial in which the results of the pretrial investigation are verified must also be effective.

Thus, it can be concluded that strict compliance with the requirements of the procedural law by the officials is not enough to conduct an effective and expeditious pretrial investigation, gather sufficient evidence and build an effective line of prosecution for its maintenance in court. The overall effectiveness of the evidentiary activity at all the stages of criminal proceeding requires the professionalism of the authorized persons, their high moral level and personal motivation.

Specific guarantees of effective activity of the investigator, interrogator, prosecutor are their ability to act in the conditions of the limited volume of information on an event of offense at the initial stage of pre-trial investigation, correct use of special technical means for detection and fixation of traces of a criminal offense, competent conduct of public and covert investigative (search) actions, effective management of tactical risks, the ability to organize interaction with other authorized units, knowledge of the specifics of the investigation of certain types of criminal offenses, capability to correctly determine the general directions and specific strategy of the investigation in each proceeding, etc. On the other side of the "barricades" of court competition, the evidential interests of suspects and accused are represented by professional defense attorneys, whose activities also require specific skills. At last, at the final stage of the proceedings, judges must give a careful assessment of the evidence provided by the parties to the criminal proceedings and make a responsible decision on the guilt or innocence of the person prosecuted which also demand characteristic skills.

Hans Gross wrote that honest citizens of the state have the right to demand that the fight against crime be carried out using all means provided to a person by the knowledge and art of investigation. This, in his opinion, can be achieved only with impeccable special training of investigators [5, p. 10]. All the above-mentioned specific skills begin to be formed in a lawyer during higher legal education and are improved in the 
course of his practical activity through self-study and accumulation of empirical experience. Therefore, it is very important that practitioners have access to modern, wellfounded, practical-oriented recommendations for proving in criminal proceedings at every stage of the formation of their professional consciousness.

Forensic recommendations of a technical nature on the proving allow the most effective use of forensic techniques to detect, record and study reflections that remain in the external environment as a result of a criminal offense. Tactical recommendations allow the investigator to conduct investigative (search) actions in the most tactful way to obtain new and verify existing evidence in criminal proceedings. Forensic recommendations of a methodological nature allow to choose the right strategy of investigation, to determine the order and priority of investigative (search) actions and organizational measures, etc. Finally, it should be noted that such recommendations are of particular value provided they are logical, structured and comprehensive.

Relevance, sufficiency, practical orientation and methodological literacy of the mentioned recommendations should be ensured by the use of appropriate scientifically substantiated sources for their formation.

Forensic recommendations for proving in criminal proceedings are the praxeological content and qualitative substance of the forensic doctrine on the collection, examination and use of evidence in criminal proceedings, which is in its constant evolutionary development [6, p. 26]. Therefore, it seems obvious that development and maintenance of the relevance of these recommendations should be based on the achievements of forensic science, the most relevant provisions of its general theory, forensic techniques, tactics and methodics.

One of the essential sources of the formation of forensic recommendations for evidence in criminal proceedings are the norms of the legislation of Ukraine on criminal liability and the achievements of the science of criminal law. The articles of the general part of the Criminal Code of Ukraine define the basic rules of qualification, while articles of a special part define the most common signs of criminal offenses. During the construction of separate methodics of investigation, criminal data on offenses serve as a basis for the formation of forensic characteristics, and together with procedural provisions on the subject of proving become the basis of standard lists of circumstances to be clarified and proven in the proceedings. Indirectly, through forensic methodics, criminal law provisions affect the technical and tactical recommendations for proving in criminal proceedings. In particular, researchers trace the correlations between the most common criminallaw features of offenses and the inherent specific traces, which creates the need to develop recommendations for detection, examination and fixation of such traces; the content of the circumstances to be clarified in the proceedings determines the tasks of inspection, interrogation and other investigative (search) actions, etc.

Criminal procedural legislation defines procedural requirements for evidentiary activity in criminal proceedings, which cannot be ignored during the development of relevant forensic recommendations. In particular, Sec. I of the CPC of Ukraine defines the tasks of criminal proceedings and the scope of criminal procedural legislation (Chapter 1), formulates the general principles of criminal proceedings, which too apply to evi- 
dentiary activities (Chapter 2), regulates the legal status of the subjects of proving (Chapter 3), defines the concepts, properties and procedural sources of evidence, the essence of proving in criminal proceedings (Chapter 4), establishes the requirements for recording the course and results of evidential activity (Chapter 5). Sec. II of the Code determines the procedure for obtaining temporary access to things and documents, temporary seizure and seizure of property, which are among the means of gathering evidence. Sec. III, IV, $\mathrm{V}$ of the Code establish the procedural order of proving at the stages of pre-trial investigation, trial and review of court decisions, respectively. Sec. VI of the CPC of Ukraine regulates the specifics of proving while applying special of criminal procedures, sec. IX determines opportunities to gather evidence in international cooperation. In addition to the CPC of Ukraine, evidentiary activity in criminal proceedings is regulated by a number of special laws and international treaties that are part of criminal procedural legislation.

The theoretical basis for constructing recommendations for proving in criminal proceedings should clearly include the achievements of the science of criminal procedure, in particular criminal procedural theory of evidence. Procedural scientific provisions focus on the study of the nature of evidence, their properties and procedural sources, the procedural status and capabilities of the subjects of proving, the essence of the evidentiary activity and the requirements of the law on it. Based on the regulatory requirements and theoretical provisions of the theory of evidence, forensics should offer the most rational procedure for authorized entities to collect and study evidence in tactical recommendations, as well as to use evidence in methodological recommendations.

Part 2 of Art. 1 of the CPC of Ukraine refers to the criminal procedure legislation, among other things, international agreements, the binding nature of which was approved by the Verkhovna Rada of Ukraine. One of the most relevant international acts in this aspect is the Convention for the Protection of Human Rights and Fundamental Freedoms, signed by Ukraine in November 1995 and ratified in July 1997. The prohibition of torture, the guaranteed rights to life, liberty and security of person, to a fair trial, respect for private and family life, etc. established by the Convention, have a significant impact on the content of forensic recommendations for investigative actions.

However, in this aspect is the practice of the European Court of Human Rights established on the basis of the Convention is more interesting. It has a precedent nature and in accordance with Art. 8,9 of the CPC of Ukraine must be taken into account when applying the principle of the rule of law and the provisions of criminal procedure law in criminal proceedings.

Art. 13 of the Law of Ukraine "On the implementation of decisions and application of the case law of the European Court of Human Rights" [7], defines a list of general measures taken to ensure compliance with the provisions of the Convention, violation of which is established by the ECtHR, and to eliminate systemic deficiencies that underlie the violation identified by the court. In particular, it is a question of making changes in practice of application of the national legislation, maintenance of professional training of law enforcement officers and study of the convention and practice of the ECtHR. It is forensic recommendations for the collection, examination and use of evidence, aimed at improving the practice of proving in criminal proceedings, that are the source of training 
for investigators, interrogators and prosecutors who carry out evidential activities. Therefore, such recommendations should be adjusted in a timely manner in accordance with current ECtHR practice.

Judicial decisions of ECtHR, as a source of forensic recommendations for the collection, examination and use of evidence in criminal proceedings can be divided into two categories:

1) decisions that affect the procedural requirements for proving in general;

2) decisions that affect specific tactical or methodological recommendations for proving in criminal proceedings.

Examples of the first category include the decisions in the cases of "Chmil v. Ukraine" [8], "Geletey v. Ukraine" [9], "Zakshevsky v. Ukraine" [10] and others. The analysis of case law has shown that judges actively refer to the listed and other similar decisions when examining and evaluating the evidence submitted by the parties of court hearing.

As an example of the second category, we can cite the legal position set out in the decision of ECtHR in the case "A.V. against Ukraine" (Application № 65032/09, the decision became final on 29.04.2015) [11]. The Court stated in paragraph 60 of the judgment that "the waiver of this right [the right of access to a lawyer] must, inter alia, be granted in an unambiguous manner and be accompanied by minimum guarantees commensurate with its importance. The necessary guarantees of the right to legal aid, among other things, indirectly reinforce the obligation of the authorities to establish that the person did not wish to exercise this right in a specific period of time".

On the basis of the cited legal position it is possible to formulate the tactical recommendation for the authorized persons who carry out investigative (search) actions concerning the suspect or the accused of the following content. If after the person is in accordance with Part 3 of Art. 223 of the CPC of Ukraine notified of their rights (including guaranteed by parts 1, 2 of Art. 20 of the CPC the right to legal assistance by a qualified defense counsel), such person has not clearly stated a desire to exercise such a right or refusal to use it, the authorized person must ask the respondent if he wants to use the right to defense, and record the answer in the protocol of the investigative (search) action.

The actions of the authorized personnel described by us do not entail serious additional procedural costs, but allow to effectively provide the guaranteed by the Art. 63 of the Constitution of Ukraine [12], subparagraph "C" of paragraph 3 of Art. 6 of the ECHR and Art. 20 of the CPC of Ukraine the right of the suspect, accused to have qualified legal assistance of a defense counsel. Ensuring the implementation of this right is crucial, because its violation during the investigative (search) action in accordance with paragraph 3 of Part 2 of Art. 87 of the CPC of Ukraine is a significant violation of human rights and freedoms and must inevitably entail the recognition of evidence obtained in the course of such an investigative (search) action as inadmissible.

Thus, we can conclude that the case law of the European Court of Human Rights affects both the procedural requirements for evidence in general and specific tactical and methodological recommendations for proving in criminal proceedings, and is therefore a crucial source of forensic recommendations. 
Undoubtedly, forensic recommendations on proving should be based on the accumulated experience of investigative and judicial practice. The connection of recommendations with practice allows to identify and scale the best trends in detection, investigation and prevention of criminal offenses, to find and correct common mistakes, to test new theoretical provisions. In order to study practical experience, it is customary to investigate the materials of criminal proceedings (protocols of investigative (search) actions, written reports of suspicion, indictments, expert reports, etc.) and court decisions in which the results of evidence of the parties receive critical assessment.

Last but not least, a specific feature of forensic science is its integration function to implement in practice of detection, investigation and prevention of criminal offenses achievements of other (non-legal) sciences. Such integration is most clearly traced on the example of the formation of technical-forensic recommendations for proving in criminal proceedings. Modern methods of detection, examination and fixation of traces, operational and expert research of forensically significant objects are based on the achievements of natural and technical scientific disciplines. Tactical recommendations for verbal investigative (search) actions are based on the provisions of practical psychology, recommendations on the organization of investigation and trial - on the provisions of praxeology and scientific organization of labor, etc. Methodical guidelines for the investigation of certain types of criminal offenses related to a particular area of human activity should take into account the provisions of the sciences, that serve such activities. For example, the formation of a methodology for investigating criminal offenses against journalists requires the application of the provisions of the theory of journalism; methodology of investigating economic offenses - the provisions of economic theory; methodology of investigating environmental offenses - environmental science and so on.

Conclusions. Thus, the sources of formation of forensic recommendations for the collection, examination and use of evidence in criminal proceedings are:

- the most relevant provisions of forensic science, a component of which is the forensic doctrine of the collection, examination and use of evidence in criminal proceedings;

- provisions of the legislation of Ukraine on criminal liability and provisions of the science of criminal law, which determine the general rules of qualification and minimum necessary list of signs of criminal offenses;

- provisions of the criminal procedural legislation of Ukraine and achievements of science of criminal procedure which establish procedural requirements concerning evidentiary activity of the authorized personnel in criminal proceedings;

- legal positions formulated by the European Court of Human Rights, which affect both the procedural requirements for evidential activity in general and the specific tactical and methodological recommendations for proving;

- the practice of detection, investigation and trial of criminal offenses;

- scientific provisions of other (non-legal) sciences, which are integrated by forensic science and implemented in law enforcement practice.

The identification of such sources is the first stage in the development of methodological foundations for the formation of forensic recommendations for the collection, 
examination and use of evidence in criminal proceedings while developing of the eponymous forensic doctrine. The study of the nature of evidence and evidentiary activity from the standpoint of forensic science seems promising in this area.

\section{Використані джерела:}

1. Велика украӥнська юридична енциклопедія : у 20 т. Т. 20 : Криміналістика, судова експертиза, юридична психологія. Редкол. : В. Ю. Шепітько (голова) та ін., 2018. 952 с.

2. Кримінальний процесуальний кодекс України. Кодекс України; Закон, Кодекс від 13.04.2012 № 4651-VI // База даних «Законодавство України» / Верховна Рада України. URL : https:/ / zakon.rada.gov.ua/laws/show/4651-17. (дата звернення: 23.11.2020).

3. Конвенщія про захист прав людини і основоположних свобод. Рада Європи; Конвенщія, Міжнародний документ від 04.11.1950 // База даних «Законодавство України» / Верховна Рада України. URL: https://zakon.rada.gov.ua/laws/show/995_004. (дата звернення: 23.11.2020).

4. Справа «Зоріна та інші проти України» (Заява № 20295/07 та 3 інші заяви). Європейський суд 3 прав людини. URL: https://zakon.rada.gov.ua/laws/show/974_e22. (дата звернення: 23.11.2020).

5. Гросс Г. Руководство для судебных следователей как система криминалистики. Новое изд., перепеч. С изд. 1908 г. Москва, 2002. 1908 с.

6. Коваленко А. Наукові передумови формування та розвитку криміналістичного вчення про збирання, дослідження та використання доказів у кримінальному провадженні. Науковий вісник Національної академії внутрішніх справ, № 113, 4, 24-30. (Лют. 2020), С. 24-30.

7. Про виконання рішень та застосування практики Європейського суду з прав людини. Закон України від 23.02.2006 № 3477-IV // База даних «Законодавство України» / Верховна Рада України. URL : https://zakon.rada.gov.ua/laws/show/3477-15. (дата звернення: 24.11.2020).

8. Справа «Чміль проти України» (Заява № 20806/10) Європейський суд 3 прав людини. URL: https:/ / zakon.rada.gov.ua/laws/show/974_b45. (дата звернення: 24.11.2020).

9. Справа «Гелетей проти України» (Заява № 23040/07) Європейський суд з прав людини. URL: https:/ /zakon.rada.gov.ua/laws/show/974_c52. (дата звернення: 24.11.2020).

10. Справа «Закшевський проти України» (Заява № 7193/04) Європейський суд 3 прав людини. URL : https://zakon.rada.gov.ua/laws/show/974_b60. (дата звернення: 24.11.2020).

11. Справа «А.В. проти Украӥни» (Заява № 65032/09). Свропейський суд 3 прав людини. URL: https://zakon.rada.gov.ua/laws/show/974_a77. (дата звернення: 24.11.2020).

12. Конституція України. Конституція, Закон від 28.06.1996 № 254к/96-ВР / / База даних «Законодавство України» / Верховна Рада України. URL : https:/ / zakon. rada.gov.ua/ laws/show/254\%D0\%BA/96-\%D0\%B2\%D1\%80 . (дата звернення: 24.11.2020).

\section{References:}

1. Velyka ukrainska yurydychna entsyklopediia : u 20 t. T. 20 : Kryminalistyka, sudova ekspertyza, yurydychna psykholohiia (2018). V. Yu. Shepitko (Ed.) et al. [in Ukrainian].

2. Kryminalnyi protsesualnyi kodeks Ukrainy. Kodeks Ukrainy (2012) Baza danykh "Zakonodavstvo Ukrainy". Verkhoona Rada Ukrainy - Verkhovna Rada of Ukraine. N. p. URL : https://zakon.rada.gov.ua/laws/show/4651-17. [in Ukrainian]. 
3. Konventsiia pro zakhyst prav liudyny i osnovopolozhnykh svobod (1950) Baza danykh "Zakonodavstvo Ukrainy". Verkhoona Rada Ukrainy - Verkhovna Rada of Ukraine. N. p. URL : https://zakon.rada.gov.ua/laws/show/995_004. [in Ukrainian].

4. Sprava «Zorina ta inshi proty Ukrainy» (Zaiava № 20295/07 ta 3 inshi zaiavy) (2019). Yevropeiskyi sud z prav liudyny - European Court of Human Rights. URL : https://zakon.rada. gov.ua/laws/show/974_e22. [in Ukrainian].

5. Gross, G. (2002) Rukovodstvo dlja sudebnyh sledovatelej kak sistema kriminalistiki. Novoe izd., perepech. S izd. 1908 g. Moskva, 1908. [in Russian].

6. Kovalenko A. (2020) Naukovi peredumovy formuvannia ta rozvytku kryminalistychnoho vchennia pro zbyrannia, doslidzhennia ta vykorystannia dokaziv u kryminalnomu provadzhenni. Naukooyi visnyk Natsionalnoi akademii vnutrishnikh sprav - Scientific Bulletin of the $\mathrm{Na}$ tional Academy of Internal Affairs, 113, 4, 24-30. [in Ukrainian].

7. Pro vykonannia rishen ta zastosuvannia praktyky Yevropeiskoho sudu z prav liudyny (2006) Baza danykh "Zakonodavstvo Ukrainy". Verkhoona Rada Ukrainy - Verkhovna Rada of Ukraine. N. p. URL: https:/ / zakon.rada.gov.ua/laws/show/3477-15. [in Ukrainian].

8. Sprava «Chmil proty Ukrainy» (Zaiava № № 20806/10) (2016). Yevropeiskyi sud z prav liudyny - European Court of Human Rights. URL : https://zakon.rada. gov.ua/laws/show/ 974_b45. [in Ukrainian].

9. Sprava « Heletei proty Ukrainy » (Zaiava № 23040/07) (2018). Yevropeiskyi sud z prav liudyny - European Court of Human Rights. URL : https://zakon.rada.gov.ua/laws/show/974 c52. [in Ukrainian].

10. Sprava «Zakshevskyi proty Ukrainy » (Zaiava № 23040/07) (2016). Yevropeiskyi sud z prav liudyny - European Court of Human Rights. URL: https ://zakon.rada.gov. ua/laws/show/ 974_b60. [in Ukrainian].

11. Sprava «A. V. proty Ukrainy» (Zaiava № 65032/09) (2015). Yevropeiskyi sud z prav liudyny - European Court of Human Rights. URL : https://zakon.rada.gov.ua/laws/show/974_a77. [in Ukrainian].

12. Konstytutsiia Ukrainy (1996). Baza danykh "Zakonodavstvo Ukrainy". Verkhorna Rada Ukrainy - Verkhorna Rada of Ukraine. N. p. URL : https://zakon.rada.gov.ua/laws/show/ 254\%D0\%BA/96-\%D0\%B2\%D1\%80. [in Ukrainian].

Стаття надіӥшла до редколегї 26.11.2020

Коваленко А. В., кандидат юридичних наук, доцент кафедри кримінально-правових дисциплін

Луганського державного університету внутрішніх справ імені Е. О. Дідоренка (м. Сєвєродонецьк, Україна)

\section{ДЖЕРЕЛА ФОРМУВАННЯ КРИМІНАЛІСТИЧНИХ РЕКОМЕНДАЦІЙ ЩОДО ЗБИРАННЯ, ДОСЛІДЖЕННЯ ТА ВИКОРИСТАННЯ ДОКАЗІВ У КРИМІНАЛЬНОМУ ПРОВАДЖЕННІ}

Статтю присвячено визначенню основних джерел формування криміналістичних рекомендацій щодо збирання, дослідження та використання доказів у кримінальному провадженні. Загальна ефективність доказової діяльності на етапах досудового 
розслідування та судового розгляду вимагає професіоналізму уповноважених осіб, їх високого морального рівня та особистої вмотивованості. Специфічні навички правозастосовувачів починають формуватися ще під час отримання ними вищої юридичної освіти і вдосконалюються в ході практичної діяльності через самонавчання та накопичення емпіричного досвіду. Тому надважливо, щоб практик на кожному етапі формування своєї професійної свідомості мав доступ до розроблених науковцями сучасних, обгрунтованих, практично-спрямованих рекомендацій щодо доказування у кримінальному провадженні. Актуальність, достатність, практична спрямованість та методична грамотність згаданих рекомендацій мають забезпечуватися використанням відповідних науково обгрунтованих джерел для їх формування.

Джерелами формування криміналістичних рекомендацій щодо збирання, використання та дослідження доказів у кримінальному провадженні виступають: найбілыш актуальні положення криміналістичної науки, складовою якої є криміналістичне вчення про збирання, дослідження та використання доказів у кримінальному провадженні; норми законодавства України про кримінальну відповідальність та положення науки кримінального права, які визначають загальні правила кваліфікації, мінімально необхідний перелік ознак кримінальних правопорушень; норми кримінального процесуального законодавства України та здобутки науки кримінального процесу, які встановлюють процесуальні вимоги щодо доказової діяльності уповноважених осіб у кримінальному провадженні; правові позиції, сформульовані Європейським судом з прав людини, що впливають як на процесуальні вимоги щодо доказування в цілому, так і на конкретні тактичні й методичні рекомендації щодо доказування; практика розкриття та розслідування кримінальних правопорушень; наукові положення інших (не юридичних) наук, які інтегруються криміналістикою та впроваджуються в правоохоронну практику.

Ключові слова: кримінальне провадження, доказування, збирання, дослідження, використання доказів, криміналістичні рекомендації.

Коваленко А. В., кандидат юридических наук, доцент кафедры уголовно-правовых дисциплин Луганского государственного университета внутренних дел имени Э. А. Дидоренко (г. Северодонецк, Украина)

\section{ИСТОЧНИКИ ФОРМИРОВАНИЯ КРИМИНАЛИСТИЧЕСКИХ РЕКОМЕНДАЦИЙ ПО СБОРУ, ИССЛЕДОВАНИЮ И ИСПОЛЬЗОВАНИЮ ДОКАЗАТЕЛЬСТВ В УГОЛОВНОМ СУДОПРОИЗВОДСТВЕ}

Статья посвящена выявлению основных источников криминалистических рекомендаций по сбору, исследованию и использованию доказательств в уголовном судопроизводстве. Автор подчеркивает, что актуальность, достаточность, практическая ориентированность и методологическая грамотность таких рекомендаций должны обеспечиваться за счет использования соответствующих научно обоснованных источников для их формирования. 
Источниками формирования таких рекомендаций являются: наиболее актуальные положения науки криминалистики; положения законодательства Украины об уголовной ответственности и положения науки уголовного права; положения уголовнопроцессуального законодательства Украины и достижения уголовно-процессуальной науки; правовые позиции, сформулированные Европейским судом по правам человека; практика раскрытия, расследования и судебного преследования уголовных преступлений; научные положения других (неюридических) наук, которые интегрируются криминалистикой и внедряются в правоприменительную практику.

Ключевые слова: уголовное производство, доказательства, сбор, исследование, использование доказательств, судебно-медицинские рекомендации.

DOI: 10.33766/2524-0323.92.176-188

УДК 343.131.2

В. В. Навроцька, кандидат юридичних наук, доцент, доцент кафедри кримінально-правових дисциплін Львівського державного університету внутрішніх справ (м. Львів, Україна) e-mail: superviranavr@gmail.com iDhttps: //orcid.org/0000-0002-3407-7984

\section{ЗАКРИТИЙ СУДОВИЙ РОЗГЛЯД ЯК ГАРАНТІЯ НЕРОЗГОЛОШЕННЯ ОХОРОНЮВАНИХ ЗАКОНОМ ТАЕМНИЦЬ}

У статті констатовано, що можливість проведення закритих судових засідань є однією із процесуальних гарантій нерозголошення охоронюваних законом таємниц. Зазначено, що здійснювати розгляд питання про закрите судове засідання слід у кожному випадку, коли для цього виявляються підстави, незалежно від наявності клопотань сторін. Запропоновано доповнити КПК України нормою, яка б передбачала недопустимість розголошення даних закритого судового розгляду, а в КК України, своєю чергою, передбачити відповідальність за порушення такої заборони. Указано, що одним із способів захисту таємниці у сфері кримінальної процесуальної діяльності може бути розділення кримінального провадження стосовно окремих підозрюваних, обвинувачених у частині епізодів злочинної діяльності, коли в них містяться відомості, котрі не підлягають розголошенню. 3 огляду на це, було запропоновано нову редакцію ч.3 ст. 217 КПК України 2012 p.

Також піддано критиці положення ч.3 ст. 27 КПК України; запропоновано норму, згідно з якою у відкритому судовому засіданні листування та запис переговорів, що містять інформацію суто особистого характеру чи відомості про приватне життя, можуть бути оголошені лише зі згоди осіб, яких вони стосуються. Піддано критиці позицію, згідно з якою розгляд проваджень про застосування примусових заходів медичного характеру завжди має бути відкритим.

Ключові слова: закритий судовий розгляд, відкрите судове засідання, охоронювані законом таємнищі, гарантія нерозголошення, захист інформації, гласність.

(C) Навроцька В. В., 2020 